\title{
Some ethical problems of hazardous substances in the working environment ${ }^{1}$
}

\author{
W. R. LEE \\ From the Department of Occupational Health, University of Manchester
}

\begin{abstract}
Exposure of persons to conditions at work may involve some risk to health. It is not possible always to ensure that exposure can be kept below a level from which it may be categorically stated that there is no risk. The decision that has to be made, what ought to be done, poses an ethical problem. What principles are available for examining such ethical problems? Two theories from the study of ethics seem relevant. On the one hand Intuitionism asserts that we possess a moral sense which, correctly applied, enables us to determine what is a right action. The familiar use of 'conscience' and the teachings of some of the influential Western religions follow this theory. On the other hand Utilitarianism (in particular Objective Utilitarianism) asserts that we may judge the rightness of an action by looking at its consequences. This theory, translated into legislative reform, has provided a substantial basis for much of the social reforming legislation of the last century. In economic terms it appears as cost benefit analysis. Despite its attraction and almost plausible objectivity, Utilitarianism requires the quantification and even costing of consequences which cannot always be measured (for example, emotions) but which form an important part of the totality of life. Decisions about the right course of action are required politically but cannot always be made objectively. They may require an element of judgement-a correct application of the moral senseto use the Intuitionists' phrase. Doctors, used to making ethical decisions in the clinical setting, must examine carefully their role when contributing to ethical decisions in the industrial setting.
\end{abstract}

In a recent edition of his book on Industrial Law, Professor Wood (1972), who was Vice-Chairman of the Robens Committee on Safety and Health at Work, wrote

"The conduct of any industrial undertaking involves some element of risk to the people employed. In mining and quarrying the risks are obvious and constant. An element of danger is something to which, in greater or less degree, the employees must get accustomed."

Occupational Medicine provides a special opportunity to study the effects of hazardous substances on persons exposed to them. Firstly, the environment can frequently be described with some degree of accuracy, both with regard to its constituents and to their concentrations. Secondly, the exposed persons generally form a well-defined population that may be under medical surveillance which can monitor the expected specific effects of one or more of the identi-

${ }^{1}$ Based on a paper read before the Manchester Literary \& Philosophical Society, 2 February 1977.

Received for publication 31 March 1977

Accepted for publication 16 June 1977 fied environmental constituents: for example, pulmonary function in asbestos workers, or the urinary metabolites of chlorinated hydrocarbons from persons exposed to some solvents.

As a result, either the general environment or the personal microenvironment of the worker may be changed, so that those effects which are detected in him are not harmful. This statement implies, firstly, that it has been agreed what is a harmful concentration of the hazardous material in the working environment and, secondly, that there is an administrative procedure for reaching such a decision.

\section{Principles regulating decisions}

Occupational Medicine defines the permissible working environment in terms such as Threshold Limit Value. This and other terms, although clearly defined (Department of Employment, 1976), are sometimes wrongly taken to mean that people will be safe as long as hazardous substances are kept below the threshold, or as long as the allowable maximum is not exceeded.

However, in many instances we are dealing not so 
much with a clearly defined boundary as with a probability. Three examples will be taken. First, the current reasoning of the International Commission on Radiological Protection (1959) is that:

"Any departure from the environmental conditions in which man has evolved, may entail a risk of deleterious effects. It is, therefore, assumed that long-continued exposure to ionising radiation additional to that due to natural radiation involves some risk. However, man cannot entirely dispense with the use of ionising radiation and, therefore, the problem in practice is to limit the radiation dose to that which involves a risk that is not unacceptable to the individual and to the population at large."

From data of Thorne and Vennart (1976), the risk, in the international standard, from whole body radiation (5 rem/annum), which people working in hospital $x$-ray departments, factories, and nuclear power plants are asked to accept may be calculated to be about 6.5 cases of fatal cancer per 10000 per year. (Thorne and Vennart calculate a nominal risk of nine cases $/ 10^{4}$ exposed persons/year. From the first table in their paper the nine cases are seen to comprise 6.5 cases of fatal cancer and 2.5 cases of hereditary disease.) The great majority of occupationally-exposed workers are kept well below the accepted standard of $5 \mathrm{rem} / \mathrm{year}$.

The second example is from a report on the risk of asbestosis from chrysotile (white) asbestos dust (Lane et al., 1968) which concluded:

"As long as there is an appreciable amount of dust in the air, the Committee recognises that there may be some risk to health."

From the available evidence linking known exposure to known concentrations of chrysotile dust with the occurrence of the earliest detectable changes of asbestosis, whether clinical or radiological, the risk of developing asbestosis was calculated to be about one per cent for workers exposed to a concentration of two fibres per $\mathrm{cm}^{3}$ over a working lifetime of 50 years. This recommendation, like the radiation one just cited, refers not to a safe level but specifies the risk.

The third example comes from a study of heat stress. Wyndham et al. (1965) showed that the relationship between core body temperature and the sweat rate takes the form of a sigmoid curve with the steep part between core body temperature of $37.5^{\circ} \mathrm{C}$ $\left(99.5^{\circ} \mathrm{F}\right)$ and $38.6^{\circ} \mathrm{C}\left(101 \cdot 5^{\circ} \mathrm{F}\right)$. When the core body temperature exceeds $39.2^{\circ} \mathrm{C}\left(102.5^{\circ} \mathrm{F}\right)$ there is no further increase in sweating. From these findings they suggested that conditions likely to lead to a rectal temperature above $39.2^{\circ} \mathrm{C}\left(102.5^{\circ} \mathrm{F}\right)$, or an oral temperature above $38.6^{\circ} \mathrm{C}\left(101 \cdot 5^{\circ} \mathrm{F}\right)$, were 'excessive'. In a later investigation in a hot Australian mine Wyndham et al. (1967) recommended that work should stop when there was a probability of 1 man in $\mathbf{2 0 0 0}$ reaching this oral temperature, when he might suffer from heat collapse and/or acute heat fatigue.

The first example relating to radiation refers to a risk of death whereas the others, relating to asbestos and heat stress, refer to the risk of acquiring a diseased state which might, or might not, be fatal.

There is, then, no definable boundary between safe and hazardous, but a zone of uncertainty, in which we can only describe our position by referring to a changing probability of an effect being produced. We ought, therefore, to consider what principles we should use to govern our decisions on the amounts of certain materials to which work-people may be exposed. Because questions like this arise in connection with specific problems we find that they have essentially, two components (Ewing, 1975a). The first is a request for knowledge of the facts, as in the examples cited. This information is provided by doctors, occupational hygienists, health physicists and other experts but it cannot provide an answer to the second component of the question which is, 'What ought we to do in the knowledge of these facts?' That knowledge is of a specifically ethical kind.

\section{Ethics}

This distinction may be illustrated from another field of medicine. To know the right treatment for a particular patient we must consider not only the appropriate medical treatment, which is the specialised scientific knowledge of medicine, but whether or not he ought to be treated, which is an ethical question. In the great majority of instances the answer to the second part is a simple 'yes', but, as the Archbishop of Canterbury has recently discussed, there are occasions when the question needs to be considered more deeply (Coggan, 1977).

The distinction between science and ethics, according to Aristotle, is that science deals with matters 'which cannot be otherwise' such as the relationship of the squares on a right-angled triangle, or the chemical composition of water. Ethics on the other hand considers the motives which lead men to act as they do, and therefore deals with matters 'which may be otherwise'.

Although doctors have been faced with such ethical problems since the beginnings of medicine, the ethical question of what ought to be done about the working environment is not one which the doctor takes alone. It is useful and possibly important for doctors and others concerned with ethical decisions on the working environment to have thought about this field and, perhaps, to recognise some of the 
landmarks, but because ethics is not an exact science, we cannot expect to find ready-made answers (Joad, 1938a).

Although frequently concerned with ethical problems, doctors are perhaps like one of Molière's characters who suddenly realised that he had been speaking prose for more than $\mathbf{4 0}$ years without realising it. In the same way that we learn to speak and write prose better by trying to understand some of the rudiments, so we may clarify our thinking on some of these ethical issues by trying to understand what it is we are doing. "I would assign to ethics, as its main business, the task not of obtaining new knowledge but of clarifying the knowledge that we already possess." (Joad, 1938b.)

\section{Our imperfect knowledge}

We can start by considering the imperfection of our knowledge even of the physical objects which we see. Blakemore (1976) describing the retina as the canvas of the brain commented that we conjure up everything that we know of reality from the poverty of its two-dimensional image. Furthermore, the language of vision has a slightly different dialect for every species. "The octopus probably has no 'word' for a diagonal line; it can only detect horizontal and vertical ones. Many animals have little or no ability to discriminate colour. But equally, some other species have nerve cells that can describe events that are invisible to us. Some animals can detect the plane of polarisation of light or the direction of a magnetic field." And he concluded, "We deceive ourselves if we think that our perceptual world is complete. It is what our neurons are able to tell us."

If our visual sense only imperfectly informs us about the physical world in which we live, is there a world of reality which underlies the familiar everyday world known to us through our senses?

That real or underlying world consisted, according to Plato, of eternal Forms (Garforth, 1971) such as the Forms of whiteness or of squareness. All white things are white because they participate in the Form of whiteness and similarly with squareness. Plato's is just one attempt to explain the relationship between the 'real' or 'ultimate' world and that perceived world, which we conjure up from the limited information given by our sense organs. But to us, with our problems of asbestos and ionising radiation, this theory is more interesting than a possible explanation of the physical world, for Plato's 'real' world consisted not only of eternal Forms for the physical world but included eternal Forms of moral goodness and justice. Furthermore, it was possible, for the soul of man, or at least suitably trained and educated men, the Guardians, to know about and to recognise these eternal Forms.

\section{Intuitionism}

The idea that there are unchanging eternal Forms for moral goodness and justice and that men can learn to know the fixed immutable moral right leads to one of the two fundamental groups of ethical theories, Intuitionism.

To the question, how are we to distinguish right from wrong, the Intuitionists maintain that we possess a unique faculty, a moral sense which, correctly applied, enables us to determine what is a right action and, presumably, what we ought to do about exposing people to asbestos, or what we ought to do about radiation. Objective Intuitionism holds that there is an ultimate principle which is a real and independent factor in the universe. It is recognised, but not created by the mind of man. It insists that actions are right or wrong in themselves irrespective of their consequences. The proper criterion of goodness is, according to Kant, simply 'the good will' (Paton, 1947a). It is to do one's duty simply for the sake of duty, not merely to act in accordance with duty, because that might admit selfinterest. This doctrine has been clearly and simply put in the statement that to the Objective Intuitionist, misconduct is wrong not because we disapprove of it, but we disapprove of it because it is wrong.

There are, in this doctrine, some elements in common with 'conscience'. Despite the debasement in the twentieth century of the word as one to be invoked when we want to do something which others may find diasgreeable, its use in everyday life as in 'a matter of conscience', 'conscience money', 'conscientious objector' and so on, still reveals a moral sense, a sense of duty, although not always as stark as Kant's duty.

Conscience was put by Bishop Butler (1729) at the head of the hierarchy which comprises the human mind. Christian teaching supports this view. Sometimes identifying conscience with the 'Voice of God', Christian moralists regard it as a means whereby fallible men can normally ascertain the Will of God (Cross and Livingstone, 1974). Maybe it can be trained and developed, but, ultimately, it will deliver absolute judgments to be obeyed. No matter how we may regard Christianity in the second half of the twentieth century, its teachings pervade the thinking of our Western World. Indeed, phrases like 'the sanctity of life' and the concept that life is holy because it comes from God, penetrate our thinking and our culture. (It is necessary to distinguish between the unthoughtful prolongation of life which was discussed by Coggan (1977), and the risking of the life of a healthy worker.) 


\section{Utilitarianism}

The other ethical theory, Utilitarianism, which has influenced much of our social thinking in the Western World over the past 200 years, asserts that we should judge the rightness of an action by referring to its consequences (Mill, 1871a). The ultimate consequence, or the ultimate 'good' is an experience or state of mind to which the terms happiness or pleasure are generally applied. In this context, pleasure comprises all satisfactions and joys, not only the relatively lower ones to which 'pleasure' is applied in everyday speech.

The two names associated with the influence of this theory on the development of our present society are Jeremy Bentham and J. S. Mill. The Greatest Happiness principle has had a number of modifications and generally appears as the greatest benefit for the greatest number.

In the same manner that our thinking is profoundly influenced by Intuitionism, largely through the Judaeo-Christian tradition, it is also influenced by Utilitarianism which, transformed into a philosophy of legislative reforms and social service organisation, has been a powerful influence in the development of our welfare state (Thomson, 1950).

To summarise these theories, Intuitionism states that we cannot derive the rightness or wrongness of an action but that we must refer to some external source, whether it be 'the Good' of Plato, the God of Bishop Butler, or 'the moral duty' of Immanuel Kant. Utilitarianism states that to judge the rightness of an action we should look to its consequences and, in the form which has profoundly influenced our twentieth century Western World, those consequences should provide 'the greatest benefit for the greatest number'. Some Christian moralists, arguing from the description by Thomas Aquinas of conscience as the mind of man making moral judgments (Preston, 1971) claim that it has a place in decisions of greatest benefit. Such an argument cannot apply to Objective Utilitarianism considered here.

\section{Drawbacks to the Utilitarian approach}

An example from public administration will illustrate the influence of Utilitarianism on decision-making in that field. When thinking about the assessment of 'the greatest benefit for the greatest number' we soon ask what units are to be used for the calculation. It is not surprising in present times to find that the unit used is money and to find ourselves talking of 'cost benefit analysis' and 'total loss control' (Lee, 1976). In a paper entitled 'The Value of Human Life', Hayzelden (1968) accepted that 'value' might be measured in money and began by considering the question,
'The value to whom?'. As his paper dealt with public administration he rejected as irrelevant in his context the question 'What has $\mathrm{X}$ lost when he dies?' together with the related question 'What have $X$ 's dependants lost?'. He suggested that the real question, for the public administrator at any rate, was, 'What has society lost when $\mathrm{X}$ dies?'. As an example he took the construction of an underpass at a road junction, using the financial terms of 1968 . This might cost an annual $£ 0 \cdot 6 \mathrm{~m}$ and the estimated annual benefit (in reduced traffic congestion, etc.) would be $£ 0.5 \mathrm{~m}+5$ lives saved. If each life was valued at $£ 25000$ the totar benefit would be $£ 0.625 \mathrm{~m}$, the project would be financially worthwhile; if at $£ 15000$ it would not. This example makes the simple contrast between human life and its value to society. The problem is not complicated by the question of employment and by the introduction of a third element such as shareholders, which we shall need to take into consideration.

That approach is deceptively attractive because it is based, or appears to be based, on the ethical theory which underlies our welfare state; it uses the familiar unit of money as the basis of calculation ('The common denominator is usually money, which means that money values have to be placed upon various components in (say) education, health etc.' (Williams, 1967)); and it is, or appears to be 'scientific and objective', and so avoids the difficulties entailed from using Intuitionism where there may be no agreement on the reference source for moral principles. Not everyone believes in God or accepts the teaching of Jesus Christ, while appeals to conscience have been so misused in committees and discussions as to debase its value as a currency in ethical arguments. However, despite our present-day reliance on measurement as a touchstone of knowledge, the straight Utilitarian approach in that example is coming increasingly under attack. Indeed, it is fair to say that Mill himself doubted whether the greatest benefit principle could be scientifically applied on a quantitative basis (Mill, 1871b).

A contemporary philosopher writing on the practical application of Utilitarianism writes: "The way to evaluate the consequences of an action does not lie through any quasi-mathematical calculus; all we can do is consider all the appreciable advantages and disadvantages of which we can think in regard to each of the alternative actions between which we are choosing, and having done this to see what the total impression is on our mind, taking into account also the degree of probability of attaining the results we desire and the risks of unintended evils" (Ewing, 1975b).

In his Jephcott Lecture, Ashby (1976) emphasised the limitations of this sort of rational analysis, citing 
the report of the Roskill Commission on a third London airport. Although the project has since been abandoned the arguments used are of interest. From cost benefit analysis Cublington was recommended because, although the disbenefit of amenity and noise level there was estimated to be some $£ 35 \mathrm{~m}$ greater than at Foulness, the benefit in time saved in travelling to and from the airport for passengers and freight would be some $£ 200 \mathrm{~m}$ greater at Cublington. On this economic assessment the Roskill Committee recommended Cublington. Even so, the Government of the day disregarded that argument and decided for Foulness. Ashby comments, "the Government took into account certain social values which are not quantifiable; they combined the hard evidence with intuition about the values." The word intuition used by Ashby contrasts with the Utilitarian (greatest benefit) approach of the Roskill Commission which he was criticising.

Ashby continues his criticism of cost benefit analysis which he appears to identify with Utilitarianism, "You cannot with any confidence rely on equations which balance cost of abatement against costs of damage for the lack of abatement. Numerically the equations cannot be solved. But politically they must be solved." While attacking cost benefit analysis, used in these circumstances, Ashby accepts the usefulness of cost effective studies. These do not attempt to resolve ethical problems, they have a subsidiary role of indicating the cheapest way of achieving a level of protection once that has been agreed.

\section{Application to Occupational Medicine}

In the foregoing discussion on the application of Utilitarianism and on the difficulties which such applications encounter, the examples have come from public administration. What of such problems when encountered in Occupational Medicine?

We can start by looking at attitudes to risk. In recent years a number of investigators have put figures to these risks (Sowby, 1965; Pochin, 1974; Ashby, 1976; Royal Commission on Environmental Pollution, 1976). It is generally accepted that the risks accepted in sporting activities may be different from those accepted in everyday life (Cohen, 1964; Pochin, 1974). The Figure presents some of the risks associated with a range of activities. It has been suggested, recently, that risks below 1 in 1 million are regarded as Acts of God and accepted without concern; risks of the order of 1 in 100000 may give rise to some warnings; at 1 in 10000 , public money is spent on trying to eliminate the risks and, if greater than about 1 in 1000, a risk is generally considered to be unacceptable (Royal Commission, 1976).

It would seem that, according to the benefits (happiness) which we hope to derive from any activity, so we set the risks we are prepared to accept. These are personal decisions we all take, generally without getting too concerned over the details of what Ewing (1975b) called the quasimathematic calculus.

But what ought we to do about asking other people such as miners or factory workers to take risks for our benefit? The word 'ought' in that last sentence reminds us that this is an ethical problem, and at the same time points us to Kant's second maxim; “Act in such a way that you always treat humanity, whether in your own person or in the person of any other, never simply as a means, but always at the same time as an end" (Paton, 1947b). The risks which might be regarded as acceptable to ask other people to take have recently been considered by Mole (1976) who suggests that there is "an objective criterion for the level of risk which could be regarded as acceptable for others, a given number of deaths of a definable kind". He arrives at this statement after considering the number of fatalities from road, rail and air transport and the number of fatalities in the home from gas and electricity and from falls, and also after considering whether the "intuitive assessments of riskiness" are based on the casualty rate per occasion of risk. Another measure of the risks which we ask others to accept is the risk to subjects in non-therapeutic research. Cardon et al. (1976) have shown that, in the United States, the annual rates for temporarily disabling, permanently disabling and fatal accidents from this cause are 37, one and zero per 1000, compared with annual rates for accidental injuries to Americans which are 50 temporarily disabling, 2 permanently disabling and 0.6 fatal (National Safety Council, 1972). This last figure, of 6 per 10000 , is remarkably close to the risk of death from all accidents, 1 in 2000, in the UK (Royal Commission, 1976) and to the maximum risk of 6.5 cases of fatal cancer per 10000 from occupational cancer (Thorne and Vennart, 1976) noted earlier.

\section{Procedure for reaching decisions}

In industry, such questions generally arise either in a Limited Liability Company where the legal owners are the shareholders, or in Nationalised Industry where the owner is the Government. There are differing views on the relationship between ownership and management. One school of thought points to the growth of the great multinational companies indicating that in the USA half of the manufacturing assets are held by 150 companies. The shareholder becomes passive and functionless. The companies exist, as it were, for themselves and their managers are concerned with the wider long-term interests of the 


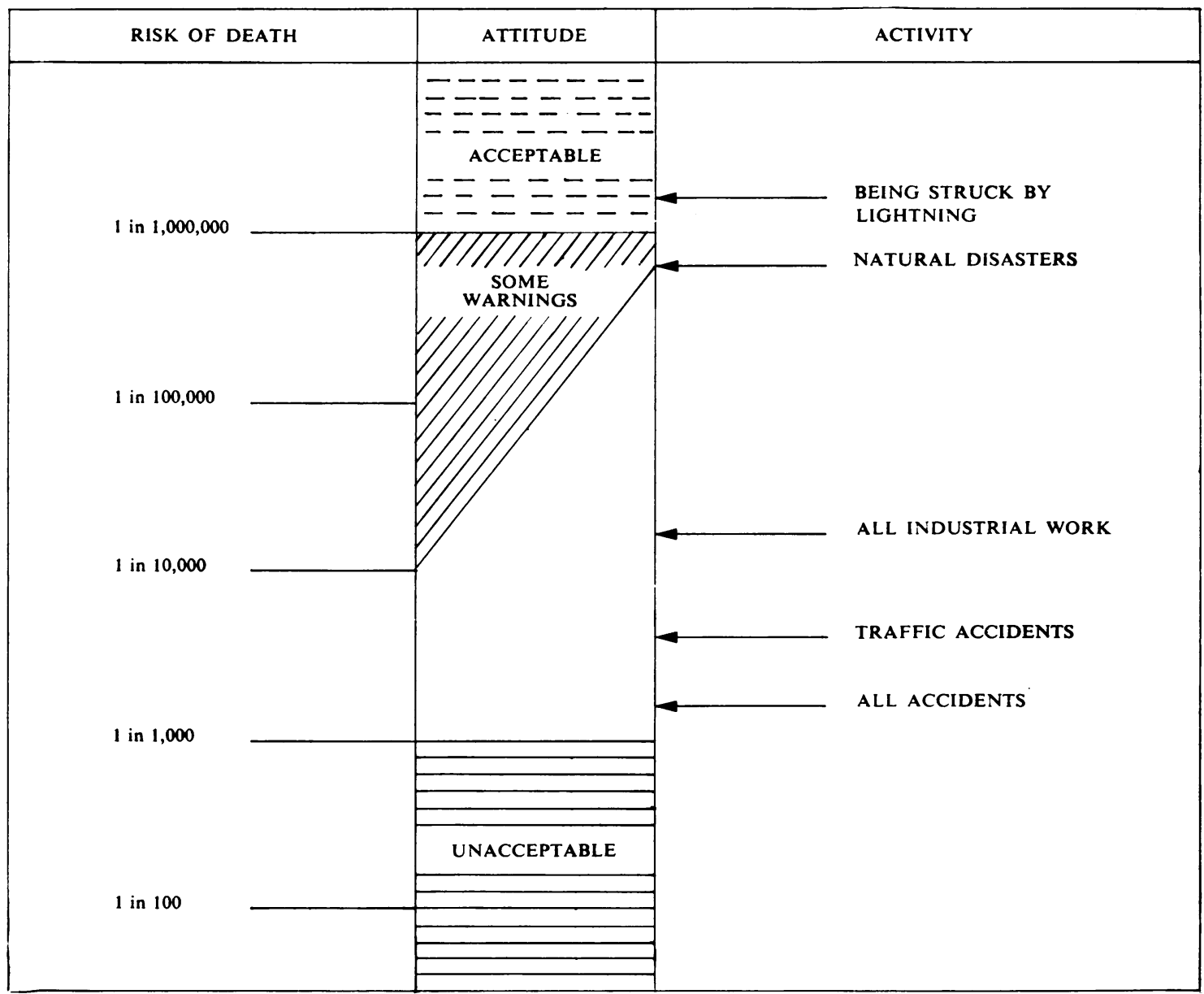

Figure Probability of death for an individual per year of exposure (orders of magnitude). (Data from Royal Commission on Environmental Pollution, 6th Report, 1976.)

company and therefore encourage a stable environment (Berle and Mears, 1948; Berle, 1957). The argument continues that this makes for greater social responsibility because the companies no longer exist just to maximise profits. The other school of thought (Friedman, 1970) maintains that the purpose of the company is maximisation of profits and that the infusion of social objectives will destroy the free enterprise system.

Managers, at least in the view of Friedman, are there to maximise profit. Who, then, will take the initiative on social issues? 'The Government', replies Friedman, and this I think would find general acceptance.

The decisions on what ought to be done have, as we have seen, two parts. One is based on factual knowledge, and the other on knowledge of what things are good or bad, and what ought to be done, that is, on ethical principles. Doctors, trained to assemble facts and draw conclusions, have been prone when working in industry to take on both parts of these decisions. At times in the past they have appeared to act like Plato's Guardians as suitably trained and educated men able to know and recognise the eternal Forms, including those of moral goodness and justice. The ethical decisions on the other hand must be taken, as they are being increasingly taken, by the three parties interested in them. That is, by industry represented by management, the work-people who may be at risk, represented by the Trades Unions, and the public, sometimes represented by the Government. Such a group will want to know the answers to the factual questions and might even, at times, require guidance on which are the appropriate factual 
questions to ask.

The doctors and scientists, who will seek to provide the answers to the factual questions, and to provide guidance in framing them, will, in my view, be able to fulfil this task better and find it more interesting if they have paused to consider the intellectual framework in which such answers and guidance are set.

I am indebted to my former teacher Emeritus Professor R. E. Lane for planting the idea of this study in my mind many years ago and then leaving it to develop. Mr Sheldon Samuels, Director of Health, Safety and Environment, Industrial Union Department, AFL-CIO, Washington, in a series of conversations has sustained my interest in this subject. My colleague, The Reverend Canon R. H. Preston, Professor of Social and Pastoral Theology, has kindly read through this paper and made valuable comments. To none of them would I attribute any of the views expressed here.

\section{References}

Astiby, Lord (1976). Protection of the environment: the human dimension. Proceedings of the Royal Society of Medicine, 69, 721-730.

Berle, A. A., and Mears, G. C. (1948). The Modern Corporations and Private Property, pp. 355-357. Macmillan: New York.

Berle, A. A. (1957). A Preliminary Discussion of the Corporation. Centre for the Study of Democratic Institutions: Santa Barbara, California.

Blakemore, C. (1976). An image of truth: Third Reith Lecture, 1976. The Listener, 666-669.

Butler, J. (1729). Upon the natural supremacy of conscience. In British Moralists, p. 214. Edited by L. A. Selby-Bigge. Clarendon Press: Oxford. 1897.

Cardon, P. V., Dommel, F. W., and Trumble, R. R. (1976). Injuries to research subjects. The New England Journal of Medicine, 295, 650-654.

Coggan, D. (1977). On dying and dying well: moral and spiritual aspects. Proceedings of the Royal Society of Medicine, 70, 75-81.

Cohen, J. (1964). Behaviour in Uncertainty, p. 118. George Allen \& Unwin: London.

Cross, F. L., and Livingstone, E. A. (1974). The Oxford Dictionary of the Christian Church, 2nd edition, p. 335. Oxford University Press: London.

Department of Employment (1976). Guidance Note EH15/76. Threshold Limit Values for 1976. HMSO: London.

Ewing, A. C. (1975a). Ethics, 10th edition, p. 10. English Universities Press: London.
Ewing, A. C. (1975b). Ethics, 10th edition, pp. 70-71. English Universities Press: London.

Friedman, M. (1970). The social responsibility of business is to increase its profits. The New York Times Magazine, p. 32. September 13.

Garforth, F. W. (1971). The Scope of Philosophy, p. 43. Longmans: London.

Hayzelden, J. E. (1968). The value of human life. Public Administration, 46, 427-442.

International Commission on Radiological Protection (1959). Recommendations. Pergamon Press: Oxford.

Joad, C. E. M. (1938a). Guide to the Philosophy of Morals and Politics, p. 87. Victor Gollancz: London.

Joad, C. E. M. (1938b). Guide to the Philosophy of Morals and Politics, p. 174. Victor Gollancz: London.

Lane, R. E., Barnes, J. M., Hichins, D. E., Jones, A G., Roach, S. A., and King, E. (1968). Hygiene standards for chrysotile asbestos dust. Annals of Occupational Hygiene, 11, 47-69.

Lee, W. R. (1976). The assessment of risks to health at work. In Equalities and Inequalities in Health, p. 65. Edited by C. O. Carter and John Peel. Academic Press: London.

Mill, J. S. (1871a). Utilitarianism, 4th edition, p. 7. Longmans, Green, Reader \& Dyer: London.

Mill, J. S. (1871b). Utilitarianism, 4th edition, pp. 11-12. Longmans, Green, Reader \& Dyer: London.

Mole, R. H. (1976). Accepting risks for other people. Proceedings of the Royal Society of Medicine, 69, 107-113.

National Safety Council (1972). Accident Facts. National Safety Council: Chicago.

Paton, H. J. (1947a). Kant's Groundwork of the Metaphysic of Morals, p. 61. Hutchinson: London.

Paton, H. J. (1947b). Kant's Groundwork of the Metaphysic of Morals, p. 96. Hutchinson: London.

Pochin, E. E. (1974). Occupational and other fatality rates. Community Health, 6, 2-13.

Preston, R. H. (1971). In A Dictionary of Christian Ethics, p. 66. Edited by J. Macquarrie. SCM Press: London.

Royal Commission on Environmental Pollution (1976). 6th Report, Cmnd 6618. HMSO: London.

Sowby, F. D. (1965). Radiations and other risks. Health Physics, 11, 879-887.

Thomson, D. (1950). England in the Nineteenth Century, p. 30. Penguin Books: London.

Thorne, M. C., and Vennart, J. (1976). The toxicity of ${ }^{9} \mathrm{Sr}$, ${ }^{226} \mathrm{Ra}$ and ${ }^{239} \mathrm{Pu}$. Nature, 263, 555-558.

Williams, A. (1967). Output budgeting and the contribution of micro-economics to efficiency in government. $C A S$ Occasional Paper, number 4, p. 13. HMSO: London.

Wood, J. C. (1972). Cooper's Outlines of Industrial Law, 6th edition, p. 351. Butterworths: London.

Wyndham, C. H., Strydom, N. B., Morrison, J. F., Williams, C. G., Bredell, G. A. G., Maritz, J. S., and Munro, A. H. (1965). Criteria for physiological limits for work in heat. Journal of Applied Physiology, 20, 37-45.

Wyndham, C. H., Allan, A. McD., Bredell, G. A. G., and Andrew, R. (1967). Assessing the heat stress and establishing the limits for work in a hot mine. British Journal of Industrial Medicine, 24, 255-271. 